\title{
Effect of Synbiotic (Saccharomyces cerevisiae ) on Performace of Murrah Buffalo Calves: Original Research Paper
}

\author{
Divya Patel", G. P. Lakhani, S. K. Joshi, K. P. S. Saini and B. Aharwal \\ Department of Livestock production and management, college of Veterinary Science and \\ Animal Husbandry, NDVSU, Jabalpur-482002, M.P., India \\ *Corresponding author
}

\section{A B S T R A C T}

\begin{tabular}{l} 
K e y w o r d s \\
$\begin{array}{l}\text { Synbiotic, Murrah } \\
\text { buffalo calves, } \\
\text { Blood parameters, } \\
\text { Body weight gain, } \\
\text { Expenditure }\end{array}$ \\
\hline Article Info \\
\hline $\begin{array}{l}\text { Accepted: } \\
\text { 22 June } 2020 \\
\text { Available Online: } \\
\text { 10 July } 2020\end{array}$ \\
\hline
\end{tabular}

\section{Introduction}

WHO recommending that farmers to stop the use of antibiotics as a growth promoter and prevent disease in healthy animals. After reduction in use of antibiotic therapy have lead to the search for new alternatives. Feed additives as Probiotic, Prebiotic and synbiotic are the examples of such alternatives. Probiotic (Saccharomyces cerevisiae) are the microorganism which contributes to the intestinal microbial balance. Probiotics have a broad range of beneficial effects such as regulation of intestinal microbial homoeostasis, stabilization of the gastrointestinal barrier function (Salminen et al., 1996), immunomodulatory effects and decrease mortality (Magalhaes et al., 2008), improving body weight gain (BWG) and feed efficiency (Abdel-Raheem et al., 2012), protection of young animals against gastrointestinal disorders like diarrhea (Galvao et al., 2005) and reduced need of antibiotic-based growth stimulants.

Prebiotics (Mannan oligosaccharide) are nondigestible carbohydrates which are not metabolized in the small intestine and 
fermented in large intestine. Prebiotics are highly effective in times of stress or increased pathogen exposure throughout the calf's lifetime (Morrison et al., 2010) with enhanced immune system (Fleige et al., 2009) and growth performances, decrease faecal coli form count and enhance growth (Ghosh and Mehla, 2012), and are found to be most effective in times of stress or increased pathogen exposure throughout the calf's lifetime. Synbiotic are the combination of Probiotic and Prebiotic which work in supplementary to each other. As the word "synbiotic" implies synergy, the term should be reserved for those products in which a Prebiotic component selectively favours a Probiotic microorganism. The principal purpose of that type of combination is improvement of survival of Probiotic microorganism in gastrointestinal tract. Probiotics beneficially influence gastrointestinal equilibrium and the Prebiotics, on the other hand, supply energy and nutrients for Probiotic bacteria. Synbiotic are more efficient than Probiotic or Prebiotic alone (Shim, 2005). The Worldwide criticism over the use of antibiotics as growth promoters due to their antibiotic resistance has lead to the utilization of feed additives as an alternative to antibiotics. Keeping the above facts in mind, an experiment will be conducted to study the effects of supplementation of Synbiotic (combination of both) in Murrah buffalo calves.

\section{Materials and Methods}

The present experiment on Murrah buffalo calves was conducted at Livestock Farm, Adhartal, Department of Livestock Production and Management, College of Veterinary Science and A.H., N.D.V.S.U., Jabalpur (M.P.). In this experiment 15 days old 12 buffalo calves were selected and randomly divided into 2 groups with 6 calves in each group as per theTable.1. The calves were housed in a well ventilated calf shed. Individual calf pens with feeding box were provided to the entire experimental animal. All the experimental animals were offered diets as per schedule shown in table 3 . The routine of milk feeding was two times a day i.e in morning $(6.30 \mathrm{am})$ and evening (5.00 pm). Synbiotic mixed with milk and offered to the calves daily in the morning up to 3 months of age. Green fodder and calf starter were fed to the all groups of animal with equal opportunity to treatment and control groups. The animals were free access to water throughout the day and night. Calf starter was formulated as per Mishra and Singh (1993) with maize, ground nut cake (GNC), wheat bran, fish meal, mineral mixture, common salt, vitamins (A, B2\&D3) with $22 \%$ crude protein (Table.2).

Body weights of all calves were recorded on weekly basis in the morning before feeding with the use of platform type electronic weighing balance. Daily feed consumption was recorded on the basis of measured quantity feed offered and left over. Cell mediated immune response was measured by skin fold response by PHA injected intradermally. The PHA was dissolved in sterile Phosphate Buffer Saline (PBS). $0.1 \mathrm{ml}$ of PBS containing $150 \mu \mathrm{g}$ of PHA was injected intradermally on a base of shaved area of posterior to the scapula using insulin syringes. The skin fold thickness was measure before injection and 2, 6, 12, 24 and 48h after injection using verniercalipper. For hematological parameters blood collection site was prepared aseptically by clipping hairs and using sterile gauze piece and spirits. $5 \mathrm{ml}$ Blood was collected from jugular vein aseptically using disposable syringe with 18 gauge hypodermic needle early in the morning at 8 am just before feeding. The blood after collection transferred to EDTA coated tube. After that the blood samples were immediately transported to laboratory in 
a box containing ices packs. All observations were performed with the help of auto analyzer except Differential leukocyte count (DLC). For DLC thin blood smear was made over a grease free slide using a drop of blood. The smears were air dry and fixed with methanol and then stain with field stain. The different leukocyte cells were counted by battlefield method and values were expressed in percentage using blood cell counter. Economics of production was calculated on the basis of cost of feed and fodder, cost of labor, cost of feed additives (Synbiotic), body weight gain etc. Data was stated as mean \pm standared error. Statistical significance of mean comparisons was calculated using ANOVA test as described by Snedecor and Cochran (1994). $P$ value of 0.05 was considered statistically significant.

\section{Results and Discussion}

\section{Hematological examination}

All the hematological parameters were recorded by using Auto analyzer except DLC.

\section{Hemoglobin concentration (g/dl)}

The Hemoglobin percentage at different periods of experimental study has been presented in table 3. Statistically there was no significant difference in hemoglobin value in different groups at different time intervals. Kim et al., (2011) reported that hemoglobin level remain unaffected by Probiotics supplementation in Holstein calves.

\section{Total Erythrocyte count $(10 \% / \mu \mathrm{l})$}

The total erythrocyte counts $\left(10^{6} / \mu 1\right)$ at different periods of experimental study has been presented in table 3. Statistically there was no significant difference in Total Erythrocyte count $\left(10^{6} / \mu 1\right)$ of different group at different time interval. Dar et al., (2017) reported that the TEC not affected by the feeding of Probiotic, Prebiotic and Synbiotic in cross bred calves.

\section{Total Leucocyte Count $\left(10^{3} / \mu 1\right)$}

The total leukocyte counts $\left(10^{3} / \mu 1\right)$ at different periods of experimental study has been presented in table 3. Statistically there was no significant difference in TLC $\left(10^{3} / \mu \mathrm{l}\right)$ in between different groups at different time intervals. Gananfar et al., (2015) reported significantly increase white blood cells in Probiotic supplemented group.

\section{Pack Cell Volume (\%)}

The PCV percentage at different periods of experimental study has been presented in table 3. Statistically there was no significant difference in PCV (\%) in between different groups at different time intervals. Kim et al., (2011) observed no significant effect of probiotc supplemented group and antibiotic supplemented group on PCV value in Holstein calves.

\section{Differential leukocyte count (DLC)}

The differential leukocyte count at different time interval of study period in experimental Murrah buffalo calves has been presented in table 4 . The table indicates that there was no significant difference between the different treatment group and control group. Our results were in agreements with the result of Agazzi et al., (2014) who reported no significant effect of feeding Probitic on any component of differential leukocytes count in calves.

\section{Cell-mediated immune response}

The results of average difference in skin fold thickness at hrs $0,2,6,12,24$ and 48 hrs after injection of PHA in group T1 and T2 
presented in table 5. Table revealed that there was increase in skin fold thickness in different treatment groups indicated increase in cellular immunity which might be attributed to increase in $\mathrm{T}$ lymphocyte stimulation and proliferation or might be due to production of cytokines which mediate different pathway of cellular immunity. The skin test provides a measure of the proliferative response potential of circulating $\mathrm{T}$ lymphocytes to an injected mitogen such as PHA. Cell thickness was increase suddenly in both groups after $2 \mathrm{hr}$ injection of PHA. There was no significant difference between control and treatment groups in average skin fold thickness. Roodposhti and Dabiri (2012) reported no significant difference in increase skin fold thickness between control and Synbiotic supplemented group.

Table.1 Grouping of the animal and their treatment

\begin{tabular}{|c|c|c|}
\hline $\begin{array}{c}\text { Groups } \\
\text { T0 } \\
\text { (Control) }\end{array}$ & Number of calves & \multicolumn{1}{|c|}{ Treatment } \\
\hline $\begin{array}{c}\text { T1 } \\
\text { (Synbiotic) }\end{array}$ & 6 & Basal diet \\
\hline
\end{tabular}

Table.2 Composition of calf starter

\begin{tabular}{|l|c|}
\hline \multicolumn{1}{|c|}{ Ingredients (\%) } & Calf starter \\
\hline Yellow maize & $50 \%$ \\
\hline Groundnut cake & $30 \%$ \\
\hline Fish meal & $7 \%$ \\
\hline Wheat bran & $10 \%$ \\
\hline Mineral mixture & $2 \%$ \\
\hline Common salt & $1 \%$ \\
\hline Vitamins ( A,B \&D3) & $15 \mathrm{gm} / 100 \mathrm{~kg}$ feed \\
\hline
\end{tabular}

Mishra and Singh (1993)

Table.3 Feeding schedule of Murrah buffalo calves

\begin{tabular}{|c|c|c|c|c|}
\hline Age (days) & Colostrum & Milk & $\begin{array}{c}\text { Calf } \\
\text { starter }\end{array}$ & $\begin{array}{c}\text { Chaffed } \\
\text { green }\end{array}$ \\
\hline $\mathbf{1 - 3}$ & $\begin{array}{c}1 / 10^{\text {th }} \text { of BW } \\
\text { in } 3 \text { feed }\end{array}$ & - & - & - \\
\hline $\mathbf{4 - 7}$ & - & $1 / 10^{\text {th }}$ of BW in 3 feed & - & - \\
\hline $\mathbf{8 - 1 5}$ & & $1 / 10^{\text {th }}$ of BW & - & - \\
\hline $\mathbf{1 5 - 2 0}$ & - & $1 / 10^{\text {th }}$ of BW & Ad lib & Ad lib \\
\hline $\mathbf{2 1 - 4 0}$ & - & $1 / 15^{\text {th }}$ of BW & $100 \mathrm{~g}$ & Ad lib \\
\hline $\mathbf{4 1 - 6 0}$ & - & $1 / 20^{\text {th }}$ of BW & $250 \mathrm{~g}$ & Ad lib \\
\hline $\mathbf{6 0 - 9 0}$ & & Milk is gradually reduced & $500 \mathrm{~g}$ & Ad lib \\
\hline
\end{tabular}

(Reddy, 2009) 
Table.4 Effect of Synbiotic on Different hematological parameters of Murrah buffalo calves at different intervals

\begin{tabular}{|c|c|c|c|}
\hline Days & Parameters & T0 (Control) & T1 (Synbiotic) \\
\hline \multirow[t]{4}{*}{0} & TEC $\left(10^{6} / \mu I\right)$ & $6.76 \pm 0.78$ & $6.19 \pm 0.37$ \\
\hline & TLC $\left(10^{3 /} \mu \mathrm{l}\right)$ & $13.40 \pm .04$ & $14.36 \pm 1.23$ \\
\hline & Hb (g/dl) & $13.10 \pm 0.67$ & $15.44 \pm 0.87$ \\
\hline & PCV (\%) & $29.06 \pm 0.76$ & $32.44 \pm 0.65$ \\
\hline \multirow[t]{4}{*}{30} & TEC $\left(10^{6} / \mu I\right)$ & $6.2 \pm 0.13$ & $6.67 \pm 0.28$ \\
\hline & TLC $\left(10^{3 i} \mu \mathrm{l}\right)$ & $14.50 \pm 1.02$ & $16.73 \pm 1.60$ \\
\hline & Hb (g/dl) & $13.15 \pm 0.58$ & $14.38 \pm 0.62$ \\
\hline & PCV (\%) & $30.66 \pm 0.42$ & $34 . .66 \pm 1.99$ \\
\hline \multirow[t]{4}{*}{60} & TEC $\left(10^{6} / \mu \mathrm{I}\right)$ & $6.75 \pm 0.26$ & $6.86 \pm 0.53$ \\
\hline & $\operatorname{TLC}\left(10^{3 /} \mu \mathrm{l}\right)$ & $13.50 \pm 0.34$ & $15.20 \pm 0.19$ \\
\hline & Hb (g/dl) & $14.53 \pm 0.55$ & $13.86 \pm 0.65$ \\
\hline & PCV (\%) & $34.33 \pm 0.49$ & $39.50 \pm 2.40$ \\
\hline \multirow[t]{4}{*}{90} & TEC $\left(10^{6} / \mu \mathrm{I}\right)$ & $7.65 \pm 0.12$ & $7.31 \pm 0.42$ \\
\hline & TLC $\left(10^{3 /} \mu \mathrm{l}\right)$ & $15.66 \pm 0.98$ & $16.51 \pm 1.32$ \\
\hline & Hb (g/dl) & $14.70 \pm 0.66$ & $14.73 \pm 0.45$ \\
\hline & PCV (\%) & $37.66 \pm 0.42$ & $41.00 \pm 0.73$ \\
\hline
\end{tabular}

Table.5 Effect of Synbiotic on Differential leukocyte count (DLC) of Murrah buffalo calves at different intervals

\begin{tabular}{|c|c|c|c|}
\hline Days & DLC (\%) & T0 (Control) & T1 (Synbiotic) \\
\hline \multirow[t]{5}{*}{0} & Lymphocytes & $54.97 \pm 0.67$ & $60.32 \pm 4.34$ \\
\hline & Monocytes & $5.34 \pm 0.40$ & $5.30 \pm 0.68$ \\
\hline & Neutrophil & $36.66 \pm 1.77$ & $35.20 \pm 3.33$ \\
\hline & Eosinophil & $1.73 \pm 0.55$ & $1.12 \pm 0.67$ \\
\hline & Basophil & $0.32 \pm 0.45$ & $0.35 \pm 0.48$ \\
\hline \multirow[t]{5}{*}{30} & Lymphocytes & $55.16 \pm 0.74$ & $59.83 \pm 2.21$ \\
\hline & Monocytes & $7.00 \pm 0.5$ & $6.16 \pm 0.47$ \\
\hline & Neutrophil & $35.55 \pm 1.76$ & $33.00 \pm 2.06$ \\
\hline & Eosinophil & $1.83 \pm 0.16$ & $1.16 \pm 0.30$ \\
\hline & Basophil & $0.33 \pm 0.33$ & $0.16 \pm 0.16$ \\
\hline \multirow[t]{5}{*}{60} & Lymphocytes & $64.66 \pm 1.70$ & $66.00 \pm 2.51$ \\
\hline & Monocytes & $5.83 \pm 0.47$ & $6.50 \pm 0.84$ \\
\hline & Neutrophil & $31.83 \pm 1.85$ & $26.16 \pm 1.76$ \\
\hline & Eosinophil & $1.00 \pm 0.13$ & $1.50 \pm 0.22$ \\
\hline & Basophil & $0.66 \pm 0.21$ & $0.83 \pm 0.16$ \\
\hline \multirow[t]{5}{*}{90} & Lymphocytes & $65.66 \pm 0.80$ & $69.66 \pm 1.28$ \\
\hline & Monocytes & $6.83 \pm 0.65$ & $5.66 \pm 0.55$ \\
\hline & Neutrophil & $27.00 \pm 0.51$ & $25.33 \pm 1.05$ \\
\hline & Eosinophil & $1.00 \pm 0.44$ & $1.73 \pm 0.30$ \\
\hline & Basophil & $0.66 \pm 0.16$ & $0.50 \pm 0.22$ \\
\hline
\end{tabular}


Table.6 Effect of Synbiotic on cell-mediated immune response (skin-fold thickness in mm) of Murrah buffalo calves

\begin{tabular}{|c|c|c|}
\hline \multirow{2}{*}{ Hrs } & \multicolumn{2}{|c|}{ Treatments } \\
\cline { 2 - 3 } & T0 (Control) & T1 (Synbiotic) \\
\hline $\mathbf{0}$ & $4.77 \pm 0.16$ & $4.87 \pm 0.24$ \\
\hline $\mathbf{2}^{\text {nd }}$ & $8.96 \pm 0.22$ & $8.30 \pm 0.34$ \\
\hline $\mathbf{6}^{\text {th }}$ & $7.98 \pm 0.21$ & $7.55 \pm 0.30$ \\
\hline $\mathbf{1 2}^{\text {th }}$ & $5.68 \pm 0.29$ & $5.93 \pm 0.26$ \\
\hline $\mathbf{2 4}^{\text {th }}$ & $4.70 \pm 0.14$ & $5.44 \pm 0.16$ \\
\hline $\mathbf{4 8}^{\text {th }}$ & $4.63 \pm 0.14$ & $4.23 \pm 0.13$ \\
\hline
\end{tabular}

Table.7 Effect of Synbiotic on economics of rearing of Murrah buffalo calves

\begin{tabular}{|c|c|c|c|}
\hline S.No. & Particulars & $\begin{array}{c}\text { T0 } \\
\text { (Control) }\end{array}$ & T1 (Synbiotic) \\
\hline 1 & $\begin{array}{l}\text { Total milk, feed and fodder consumption per calf during the } 3 \text { month } \\
\text { experiment }\end{array}$ & & \\
\hline 1.1 & Milk consumed (liter) & 249 & 255 \\
\hline 1.2 & Calf starter $(\mathrm{kg})$ consumed & 13 & 15.5 \\
\hline 1.3 & Green fodder and dry roughage $(\mathrm{kg})$ consumed & 250 & 300 \\
\hline 1.4 & Synbiotic $(\mathrm{g})$ & & 360 \\
\hline 2 & $\begin{array}{l}\text { Expenditure on milk, feed and fodder per calf during the } 3 \text { months } \\
\text { experimental period }\end{array}$ & & \\
\hline 2.1 & Expenditure on milk (@ 48/liter) & 11952 & 12240 \\
\hline 2.2 & Expenditure on calf starter (@`23/kg) & 299 & 356.5 \\
\hline 2.3 & Expenditure on green fodder and dry roughage (@ $2 / \mathrm{kg}$ ) & 500 & 600 \\
\hline \multirow[t]{2}{*}{2.6} & Expenditure on synbiotic (@`160/kg) & & 57 \\
\hline & Total expenditure on milk, feed, fodder and feed additives & 12751 & 13253 \\
\hline 3 & $\begin{array}{l}\text { Expenditure on labour/calf for } 3 \text { months (@ } 1 \text { labour } / 24 \text { calves and } \\
\text { wage } 7500 / \text { month) }\end{array}$ & 937 & 937 \\
\hline 4 & $\begin{array}{l}\text { Miscellaneous expenditure (medicines, deworming, tagging etc.) } \\
\text { (@ } 40 / \text { calf) }\end{array}$ & 40 & 40 \\
\hline 5 & Total recurring expenditure $(/ \mathrm{kg})$ during the 3 month experimental period & 13728 & 14230 \\
\hline 6 & Reduction of total recurring expenditure in comparison to control group & - & 502 \\
\hline 7 & Body weight changes during the experimental period & - & \\
\hline 7.1 & Average initial weight of calf $(\mathrm{kg})$ & 33.33 & 34.52 \\
\hline 7.2 & Average final weight of calf $(\mathrm{kg})$ & 51.56 & 63.50 \\
\hline 7.3 & Average weight gain of calf $(\mathrm{kg})$ & 18.32 & 29.5 \\
\hline 8 & Recurring expenditure( $/ \mathrm{kg}$ ) per kg body weight gain(no.5/no.7.3) & 750 & 268 \\
\hline 9 & $\begin{array}{l}\text { Reduction of recurring expenditure }(\mathrm{kg}) \text { per } \mathrm{kg} \text { body weight gain in } \\
\text { comparison to control group }\end{array}$ & - & 272 \\
\hline 10 & $\begin{array}{l}\text { Percent decrease of recurring expenditure per } \mathrm{kg} \text { body weight gain in } \\
\text { comparison to control group }\end{array}$ & - & $35 \%$ \\
\hline
\end{tabular}


Economics of rearing of Murrah buffalo calves

Institutional rate of buffalo milk ( $₹ / \mathrm{kg}$ ), cost of calf starter and concentrate mixture based on the approved tender rate of feed ingredients at college level, market rate of green fodder and dry roughage, present wages (₹ /month) and price of synbiotic (₹ $/ \mathrm{kg}$ ) were $48.00,23.00, \quad 2.00,7500$ and 160.0, respectively. The expenditure ( $(\mathrm{kg})$ incurred for milk were 11952 and 12240 in T0 and T1 groups respectively. The expenditure (₹/kg) incurred for calf starter were 299 and 356 in T0 and T1 groups respectively. The expenditure (₹/kg) incurred for green fodder and dry roughage were 500 and 600 in $\mathrm{T} 0$ and $\mathrm{T} 1$ groups respectively. The expenditure for synbiotic was (₹) 57 in treatment group. Total expenditure (₹/calf) on milk, feed, fodder and feed additives were 12751 and 13253 in group $\mathrm{T} 0$ and $\mathrm{T} 1$ groups respectively. Expenditure on labor/ calf for three months experiment periods @ 1 labour/24 calves and wage ₹ 7500/month was 937.00 and same for both the groups. Average initial body weights of calves $(\mathrm{kg})$ were 33.33 and 34 in $\mathrm{T} 0$ and $\mathrm{T} 1$ groups respectively. Average final body weights of calves $(\mathrm{kg})$ were 51.56 and 63.50 in $\mathrm{T} 0$ and $\mathrm{T} 1$ groups respectively. Average weight gains of calves $(\mathrm{kg})$ were 18.23 and 29.5 in T0 and T1 groups respectively. Reduction of recurring expenditure (₹/kg) per $\mathrm{kg}$ body gain in comparison to control group was 272 in treatment group. Percent decrease of recurring expenditure per $\mathrm{kg}$ body weight gain in comparison to control group $35 \%$ in $\mathrm{T} 1$ group.

It is concluded that body weight was higher in treatment group due to Synbiotic (Saccharomyces cerevisiae) supplementation. Percent decrease of recurring expenditure per $\mathrm{kg}$ body weight gain in comparison to control group $35 \%$ in treatment group. From the results its obvious that Synbiotic (Saccharomyces cerevisiae) feeding helpful for economically rearing of Murrah buffalo calves.

\section{References}

Abdel-Raheem, S.M., Abd-Allah, S.M.S. and Hassanein, K.M.A. (2012). The effects of prebiotic, probiotic and synbiotic supplementation on intestinal microbialology and histomorphology of broiler chickens. International Journal for Agro Veterinary and Medical Sciences, 6(4): 277-289.

Agazzi A, Tirloni E, Stella S, Maroccolo S, Ripamonti B, Bersani C and Savoini G.(2014). Effects of species-specific probiotic addition to milk replacer on calf health and performance during the first month of life. Annal. Anim. Sci. 14 (1): 101-115.

Dar, A.H., Singh, S.K., Palod, J., Ain, K., Kumar, N., Khudda, B.S. and Farooq, F. (2017). Effect of probiotic, prebiotic and synbiotic on haematological parameters of crossbred calves. International Journal of Livestock Research, 7(4): 127-136.

Fleige, S., Preissinger, W., Meyer, H.H.D. and Pfaffl, M.W. (2009b). The immunomodulatory effect of lactulose on fed preruminant calves. Journal of Animal Science, 87(5): 1731-1738.

Galvao, K.N., Santos, J.E., Coscioni, A., Villasenor, M., Sischo, W.M. and Berge, A.C.B. (2005). Effect of feeding live yeast products to calves with failure of passive transfer on performance and patterns of antibiotic resistance in fecal Escherichia coli. Reproduction Nutrition Development, 45(4): 427-440.

Ghazanfar, S., Anjum, M.I., Azim, A. and Ahmed, I. (2015). Effect of dietary supplementation of yeast 
(Saccharomyces cerevisae) culture on growth performance, blood parameters, nutrient digestibility and fecal flora of dairy heifers. The Journal of Animal \& Plant Sciences, 25(1): 53-59.

Ghosh, S. and Mehla R.K. (2012). Influence of dietary supplementation of prebiotics (mannan oligosaccharide) on the performance of crossbred calves. Tropical Animal Health and Production, 44(3): 617-622

Kim, M.K., Lee, H.G., Park, J.A., Kang, S.K. and Choi, Y.J. (2011). Effect of feeding direct-fed microbial as an alternative to antibiotics for the prophylaxis of calf diarrhea in Holstein calves. Asian-Australasian Journal of Animal Sciences, 24(5): 643-649.

Mishra, A.K. and Singh, D. (1993). Rearing of calf: A scientific approach. Indian Dairyman, 64:526-529.

Morrison, S.J., Dawson, S., and Carson, A.F. (2010). The effects of mannan oligosaccharide and Streptococcus faecium addition to milk replacer on calf health and performance. Livestock Science, 131(2): 292-296.

Reddy, D. V. (2009). Applied Nutrition $2^{\text {nd }}$ Edn., Oxford \& IBH Publishing Company Private Limited New Delhi , $79 \mathrm{p}$.

Roodposhti, P.M. and Dabiri N. (2012). Effect of probiotic and prebiotic on average daily gain, fecal shedding of Escherichia coli, and immune system status in newborn female calves. Asian - Australasian Journal of Animal Sciences, 25(9): 1255-1261.

Shim, S.B. (2005). Effects of prebiotics, probiotics and synbiotics in the diet of young pigs. Ph.D. Thesis (Animal Nutrition), Wageningen University and Research Centre, Wageningen, Netherlands.

Snedecor, G.W and Cochran, W.G. (1994). Statistical Methods Publ. Oxford and IBH publishing co., New Delhi.

\section{How to cite this article:}

Divya Patel, G. P. Lakhani, S. K. Joshi, K. P. S. Saini and Aharwal, B. 2020. Effect of Synbiotic (Saccharomyces cerevisiae ) on Performace of Murrah Buffalo Calves: Original Research Paper. Int.J.Curr.Microbiol.App.Sci. 9(07): 3824-3831. doi: https://doi.org/10.20546/ijcmas.2020.907.447 